\title{
What Is The Real Income Of The Poor?: An Accountant's Perspective
}

Jo Ann M. Pinto, Montclair State University, USA

\begin{abstract}
The issue of poverty in America has been vastly studied in the economics, political science and sociology literatures. Conservative think tanks generally consider that official poverty statistics overstate the true nature of poverty in the U.S. while liberal organizations contend just the opposite. The aim of the current paper is not to settle this debate, but to add insights from an accountant's point of view. Specifically, the current research will calculate the income of the poor, including tax credits and transfer payments, and then construct a family budget based upon the available income. These calculations, based on a family of four living at the poverty level in 2009, will be contrasted to a family of four living at New Jersey's median income. The main finding of this paper is that the real income of the poor is substantially above their salaried income.
\end{abstract}

Keywords: poverty level; tax credits; measurement issues

\section{INTRODUCTION}

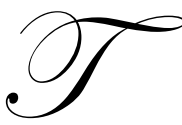

he issue of poverty has been vastly studied in the economics, sociology and political science literatures (Rector, 1998; Coontz and Folbre, 2002; Stanton, 2003; Besharov, 2006; and Bucks and Moore, 2006). Incomes of the poor have been calculated by both The Federal Reserve Board's Survey of Consumer Finances and The U.S. Census Bureau. In 2009, the official poverty level for a family of four stood at $\$ 22,050$ (U.S. Department of Health and Human Services).

According to conservative think tanks, such as the American Enterprise Institute, the official poverty level overstates the number of Americans who are actually poor. They argue that government transfer payments and unreported income mask the true numbers living in poverty in the U.S. Conversely liberal policy-makers argue that the incidence of poverty in the U.S. is far more widespread than the official numbers would indicate. Stanton, in Why Marriage Matters, argues that poverty is largely a function of marital status and that adults who finish highschool marry before having children, and marrying after the age of 20 represents only 8 percent of families who are poor.

The purpose of this study is to look behind the aggregate numbers and calculate a budget for a family of four at the poverty level in 2009. This study will include certain tax benefits and credits, as well as in-kind government transfer payments as income.

\section{METHODOLOGY}

The study will examine a hypothetical family of four consisting of married parents ages 30 and 28 , with two children ages 8 and 5. The study will calculate after-tax cash income and will incorporate government transfer payments such as food stamps, reduced-price school lunches, Section 8 housing subsidies, and subsidized health care benefits. This study will add to the extant literature by examining poverty from an accountant's point of view at the micro level of analysis.

In order to validate the reality of the proposed family budget, real estate agents, social workers, food pantry supervisors, retail managers and school officials will be interviewed to see if the findings are both reasonable and feasible. 
After the presentation and calculations are made for a family of four living at the poverty level, the analysis will replicate the family budget using the income level of another family of four living at the 2009 medium income in New Jersey as a means of comparison for the two hypothetical families.

\section{PRELIMINARY FINDINGS-FAMILY LIVING AT THE POVERTY LEVEL}

\section{Case Study}

Our hypothetical family lives in Caldwell, NJ, a middle and upper-middle class suburb in Essex County, New Jersey. This location was chosen for the following reasons: (1) it was rated the third best community in New Jersey by New Jersey Monthly magazine; (2) the town is serviced by an ample level of public transportation; (3) numerous retail outlets exist which employ low-skilled workers; and (4) the local housing stock consists of a number of rental units. The husband works full-time in a low-wage job at the poverty level. The wife is a stay-at-home mom.

\section{After-Tax Income}

Table I, calculated using the popular Turbo Tax software for tax year 2009, shows the after-tax income of the family of four after taking into considerations payroll taxes, tax deductions and tax credits. As a note, the family has no liability for federal or state income taxes given that their taxable income in both cases is zero.

Table 1: After-Tax Income For Family At The Poverty Level

\begin{tabular}{|c|c|}
\hline Gross Income & $\$ 22,050$ \\
\hline Less Payroll Taxes & 1,367 \\
\hline Social Security (6.2\%) & 320 \\
\hline Medicare (1.45\%) & 248 \\
\hline NJ Unemployment (1.125\%) & 239 \\
\hline NJ Income Tax & $\$ 19,876$ \\
\hline Net Income & 800 \\
\hline Plus Tax Credits & 4,890 \\
\hline Making Work Pay & 2,000 \\
\hline Earned Income Credit & 1,223 \\
\hline Additional Child Tax Credit & $\$ 28,789$ \\
\hline NJ Earned Income Credit & $\$ 2,399$ \\
\hline After-Tax Income & \\
\hline Monthly After-Tax Income & \\
\hline
\end{tabular}

\section{Transfer Payments}

The website, www.njhelps.org, was consulted to examine the types of government transfer payments the family would be eligible for. After entering pertinent personal information, the website determined the family was eligible for \$273 a month in food stamps, a LIHEAP (utility) credit of \$400 per year, and NJ Family Care health benefits. NJ Family Care would be available with no annual premium and no co-pays. In addition, the family would be entitled for a Section 8 housing credit of $\$ 958$ per month (www.huduser.org).

Table 2 shows the budget for the family living at the poverty level. 
Table 2: Family Budget For Family Living At The Poverty Level

\begin{tabular}{|l|c|}
\hline Cash Income & $\$ 2,399$ \\
\hline Rent & 599 \\
\hline Utilities & 200 \\
\hline Phone & 50 \\
\hline Cable TV & 65 \\
\hline Clothing & 200 \\
\hline Food & 522 \\
\hline Laundry & 50 \\
\hline Entertainment/Gifts & 200 \\
\hline Household Furniture \& Fixtures & 200 \\
\hline Transportation & 200 \\
\hline Miscellaneous & 113 \\
\hline Total Expenditures & $\mathbf{\$ 2 , 3 9 9}$ \\
\hline
\end{tabular}

\section{BUDGET CALCULATIONS}

\section{Food}

Food costs are estimated based upon a model proposed by Carlson, Lino and Fungwe (2008) of food expenditures presented by the USDA. Carlson et al. estimate daily food costs for U.S. families under three scenarios: low-cost, moderate and liberal. For the purposes of this study, the liberal food cost estimate was used, which in 2002 equaled $\$ 7.33$ per person per day. Adjusting for a 23.7\% increase in the CPI for food cost between 2002 and 2009 (Bureau of Labor Statistics, 2009), the liberal food cost per day totaled \$9.07 per person per day in 2009 , giving a monthly food cost of $\$ 1,103$. The total monthly food cost is reduced by $\$ 365$ in food stamps and $\$ 216$ from food pantry donations. Caldwell has a food pantry which allows families to take two bags of groceries per week from the pantry; the estimate here is that each bag contains $\$ 25$ worth of food.

Unfortunately, the children would not qualify for free or reduced-price school lunches given the fact that a school district must have at least $5 \%$ of its families eligible for the Federal subsidy. According to Maria Burak, town social worker for Caldwell, only about 3-4\% of Caldwell families in the district meet this requirement therefore making the family ineligible for the program.

\section{Rent}

The rental cost of $\$ 599$ was calculated as follows. A three-bedroom, six room duplex for rent in Caldwell was located for a monthly rent of $\$ 1,500$. The family would be eligible for a Section 8 housing allowance of $\$ 901$. Section 8 is a Federal (HUD) program that provides vouchers so that public-housing eligible families can obtain housing in private homes and apartments with federal subsidies. The allowance is based upon family size, location and family income.

In Essex County, New Jersey, where Caldwell is located, the fair market value of a three bedroom unit is $\$ 1,452$. According to HUD guidelines, a family should not pay more than $30 \%$ of its income for rent. At an income level of $\$ 22,050$, the monthly income cap would be $\$ 551$. However, the family can rent a unit above the area fair market rent that would add an additional $\$ 48$ a month to their portion of the payment $(\$ 1,500-\$ 1,452)$.

\section{Utilities, Phone and Cable TV}

Water and sewer are included in the monthly rental payment and are the responsibility of the landlord. The tenant would be responsible for paying heating and cooking gas and electricity. The total annual cost of this expense is estimated to be $\$ 2,800$ with a $\$ 400$ per year LIHEAP credit.

Phone would consist of a single, basic service cell phone for the household. Cable TV is basic service. 


\section{Transportation}

The family has a ten-year old car that has already been paid off. Insurance totals $\$ 600$ per year, making the monthly cost $\$ 50$. Gasoline expenditures total $\$ 100$ per month. The husband makes all repairs to the car; parts total about $\$ 400$ per year on average. The remaining transportation budget is for licenses, registration and inspection.

It should also be noted that Caldwell is a "walkable" town with ample downtown shopping, schools and entertainment located near the family's rental home. In addition, bicycles are widely seen cruising the streets.

\section{Clothing And Laundry}

Clothing expenditures total $\$ 200$ a month giving the family an annual clothing budget of $\$ 2,400$. Caldwell is served by a variety of thrift and consignment shops which can greatly reduce the price of clothing.

Laundry includes detergent and the cost of utilizing a public laundromat since the housing unit does not come with laundry facilities.

\section{Household Furniture And Fixtures}

This category includes furniture and electronics. As previously stated, Caldwell is serviced by a variety of thrift and consignment shops which offer second-hand home furnishings at drastically reduced prices. In addition, during the warm weather months, garage sales are plentiful which also offer another outlet for this type of shopping.

\section{Health Care}

The family does not incur any health care expenditures due to the fact that they are eligible for NJ Family Care. According to the www.njhelps.org website, "NJ Family Care provides full health coverage through your choice of participating Health Maintenance Organizations (HMOs) and covers almost every health care need, including doctor visits, hospitalizations, lab test, x-rays, eyeglasses, mental health services, prescription drugs, and even dental care for most children and some adults."

\section{PRELIMINARY FINDINGS-FAMILY LIVING AT THE 2009 NEW JERSEY FAMILY INCOME}

In 2009 , the median income for a family of four in New Jersey was $\$ 68,342$. Table 3 calculates the family’s after-tax income at this level.

\section{After-Tax Income}

Table 3 calculates the after-tax income of the family of four living at the median income. As opposed to the family living at the poverty level, this family does not qualify for earned-income credits and pays higher social security, medicare, unemployment and state income taxes. In addition, they have a liability for federal income taxes. $\mathrm{NJ}$ unemployment and disability is calculated as $1.125 \%$ of the first $\$ 27,555$ of taxable income.

\section{Budget Calculations}

Table 4 prepares the family budget using the same assumptions as the family of four living at the poverty level; i.e., they rent the same apartment, paying market rent. They do not qualify for any subsidies including food stamps, food pantry donations, Section 8 housing, LIHEAP energy credit, or health care. In addition, they must pay $30 \%$ of their medical premiums of $\$ 20,000$ and have additional out-of-pocket medical expenses of $\$ 2,000$. 
Table 3: After-Tax Income For New Jersey Median Income Family

\begin{tabular}{|c|c|}
\hline Gross Income & $\$ 22,050$ \\
\hline Less Payroll Taxes & 2,714 \\
\hline Federal Income Tax & 4,237 \\
\hline Social Security (6.2\%) & 991 \\
\hline Medicare (1.45\%) & 310 \\
\hline NJ Unemployment and Disability (1.125\%) & 970 \\
\hline NJ Income Tax & $\$ 59,120$ \\
\hline Net Income & 2,000 \\
\hline Plus Tax Credits & 800 \\
\hline Child Tax Credit & $\$ 61,920$ \\
\hline Making Work Pay & $\$ 5,160$ \\
\hline After-Tax Income & \\
\hline Monthly After-Tax Income & - \\
\hline
\end{tabular}

Table 4: Family Budget For A Family Living At The New Jersey Median Income

\begin{tabular}{|l|c|}
\hline Cash Income & $\$ 5,160$ \\
\hline Rent & 1,500 \\
\hline Utilities & 233 \\
\hline Phone & 50 \\
\hline Cable TV & 65 \\
\hline Clothing & 200 \\
\hline Food & 1,103 \\
\hline Laundry & 50 \\
\hline Entertainment/Gifts & 200 \\
\hline Household Furniture \& Fixtures & 200 \\
\hline Transportation & 200 \\
\hline Medical Expenditures & 667 \\
\hline Miscellaneous & 692 \\
\hline Total Expenditures & $\mathbf{5 5 , 1 6 0}$ \\
\hline
\end{tabular}

\section{SOME CAVEATS}

\section{Family Of Four Living At The Poverty Level}

The following family budget would be in place under optimal conditions. The budget does not allow for any savings, emergencies or savings for a new car should their family car become obsolete. Furthermore, some assistance programs, such as food stamps, have resource limits that cannot be exceeded in order to qualify for the programs. For example, to qualify for food stamps the family cannot have resources of more than $\$ 2,000$ to qualify for the federal subsidy. Also, there are some limitations to the transfer payments the family is likely to receive.

According to Maria Burak, Caldwell's town social worker, there is a two-year waiting list just to apply for Section 8 housing. Quite simply, the family would not be able to afford rent on their current budget alone. The aforementioned study assumes the family has been eligible for Section 8 housing for some period of time.

Furthermore, Sard and Fischer (2004) of the Center on Budget and Policy Priorities, argue that the Bush Administration's budget would substantially cut the number of households served by the Section 8 program. In 2004, two million American households were assisted by the program. They projected back in 2004 that if Bush cuts to the program were to prevail, the number of households served by the program would decrease $30 \%$ by 2009 . Housing expenditure is normally seen as the number one expenditure of families of all income classes.

Finally, the state of New Jersey is going through a deep fiscal crisis, with a budget deficit of nearly $\$ 11$ billion dollars. Certain safety-net programs, such as NJ Family Care, are slated for reductions in aid and may only 
assist children, not adults, according to Maria Burak. Health insurance premiums would be beyond the reach of the adults in this family at their current income level.

\section{Family Of Four Living At The Median Income}

The budget above results in miscellaneous expenditures of $\$ 692$ for the median income family versus $\$ 113$ for the family living at the poverty level, which comes to a difference of $\$ 579$ per month or $\$ 6,948$ on an annual basis. This is an astonishing amount given that the family of four living at the median income has a salaried income of $\$ 46,292$ more per year. Based on this calculation, the family living at the poverty level has tax credits and in-kind transfers of $\$ 39,344$ per year.

Additionally, the bread-winner in the median income family may have to spend more on clothes due to the fact that he probably has a professional position. Societal demands may also suggest that he drive a better car, eat lunch out, and contribute to charity. Like the family at the poverty level, this family also has a minimal amount left over for savings.

\section{CONCLUSION}

Poverty is a real problem in the United States and even under the best of scenarios, low-income families may find it hard to make ends meet. This study concludes that the current social safety net should be expanded and Section 8 housing should be more readily available. However, at the same time, a family living at the poverty level, given tax credits and government transfer payments, has a real income substantially above their wage income of $\$ 22,050$. Finally, the real income of the poverty level family in this study does not even take into consideration resources received from private charities.

\section{ACKNOWLEDGEMENTS}

The author would like to thank Robert Brunner of First Mountain Real Estate, Maria Burak, town social worker for the borough of Caldwell, and workers at the Caldwell food pantry for their assistance with this project.

\section{AUTHOR INFORMATION}

Jo Ann Pinto is currently an Associate Professor in the Department of Accounting, Law \& Taxation at Montclair State University where she has been employed since 1999. She holds a B.S. in Accounting from Virginia Polytechnic Institute and State University, an M.A. in Economics and an MBA in Accounting from Montclair State University and a Ph.D. in Accounting and Applied Economics from Rutgers University.

Her research interests are in the area of capital markets, taxation and economic development. Her publications have appeared in The CPA Journal, The Journal of Applied Business Research and the Journal of International Financial Management and Accounting, among others. Her teaching responsibilities include financial accounting, cost accounting, managerial accounting and financial statement analysis.

\section{REFERENCES}

1. $\quad$ Besharov, Douglas (2006). Commentary. The Wall Street Journal, March 24, 2006.

2. Bucks, Brian, Arthur B., Kennickell and Kevin B Moore. (2006). Recent Changes in U.S. Family Finances: Evidence from the 2001 and 2004 Survey of Consumer Finances. Federal Reserve Bulletin.

3. Bureau of Labor Statistics (2009). Consumer Price Index: June 2009.

4. Carlson, Andrea, Mark Lino and Thomas Fungwe (2008). USDA's Low-Cost, Moderate Cost and Liberal Food Plan: Development and Expenditure Share. Center for Nutrition Policy and Promotion, USDA.

5. Coontz, Stephanie and Folbre, Nancy (2002). Marriage, Poverty and Public Policy. Council on Contemporary Families Conference, April 26-28, 2002.

6. Mroz, Jacqueline (2010). Top Towns. New Jersey Monthly, March 2010. 
7. Rector, Robert (1998). America Has the World's Richest Poor. The Wall Street Journal, September 24, 1998.

8. Sard, Barbara and Will Fischer. (2004). Administration Seeks Deep Cuts in Housing Vouchers and

9. Conversion of Program to a Block Grant. Center on Budget and Policy Priorities.

10. Stanton, Glenn T. (2006). Why Marriage Matters, Second Edition: Twenty-Six Conclusions from the Social Sciences.

11. www.huduser.org

12. www.njhelps.org 
NOTES 